\title{
OECD Ülkelerinde İnsani Gelişme ve Finansal Gelişme Endeksleri ile Sigortacılık Prim Üretimleri Arasındaki İlişkinin İncelenmesi
}

\author{
Ersin GÜMÜŞ*
}

\section{Öz}

Çalışmanın amacı, OECD ülkelerinde insani gelişmişlik ve finansal gelişmişlik endeksleri ile sigorta prim üretimleri arasında nedensellik ilişkilerinin bulunup, bulunmadı̆̆ının incelenmesidir. Çalışmada, verileri tam ve eksiksiz olarak elde edilebilen OECD ülkelerine ait 2009 - 2016 yılları arasındaki toplam prim üretimi / gayri safi yurtiçi hasıla (TGP / GDP) verileri, IMF tarafından hesaplanan finansal gelişmişlik endeksi (FDI) verileri ile Birleşmiş Milletler tarafından hesaplanan insani gelişmişlik endeksi (HDI) verileri kullanılmıştır. Analizler için panel veri seti oluşturulmuş ve veriler arasındaki eşbütünleşme ilişkilerinin tespit edilebilmesi amacıyla Pedroni ve Kao Eşbütünleşme testleri yapılmıştır. Bu testlere ilişkin olumlu bulgular doğrultusunda nedensellik ilişkilerinin tespiti amacıyla Granger Nedensellik testleri uygulanmıștır. Granger testleri sonucunda OECD ülkelerinde, finansal gelişmişlik endeksi ile insani gelişmişlik endeksinden toplam prim üretimi / gayri safi yurtiçi hasıla değişkenine doğru nedensellik etkilerinin var olduğu tespit edilmiştir.

Anahtar Kelimeler: Sigortacılık, Finansal Gelişmişlik Endeksi, Pedroni Eşbütünleşme Testi, Kao Eşbütünleşme Testi, Granger Nedensellik Testi

Jel Kodlar1: F37, G22, I00, O15

\section{Analysis of Relationship Between the Human Development and Financial Developmet Indices with Total Gross Premiums in OECD Countries}

\begin{abstract}
The main goal of this study is to analyse whether there are causality relationships between human development and financial development indices with total gross premiums in OECD countries or not. Total gross premiums / gross domestic product (TGP / GDP) data, financial development index (FDI) data figured out by IMF and human development index data figured out by United Nations belong to OECD countries, data of which procured completely between the years of $2009-2016$ were used in this study. Panel data sets were formed for analyses and Pedroni and Kao Cointegration tests were performed to determine cointegration relationships between the data. In accordance with positive findings, Granger Causality tests were performed to determine causality relationships. As a result of Granger tests, causality effects from financial development index and human development index to total gross premiums / gross domestic product variable were found in OECD countries.
\end{abstract}

Keywords: Insurance, Financial Development Index, Pedroni Cointegration Test, Kao Cointegration Test, Granger Causality Test

Jel Codes: F37, G22, I00, O15

* Dr., T.C. Ziraat Bankası A.Ş., Eskişehir,

ORCID ID: 0000-0001-5916-2686 ersingm@gmail.com 


\section{GíRiș}

Finansal sistemler, yeni teknolojilerin yayılması ve sermaye birikiminin gerçekleşebilmesi için fon sağlama fonksiyonunu karşılamasından dolayı, ekonomik büyüme sürecinde önemli bir unsur olarak karşımıza çıkmaktadır. Gelişmiş finansal sistemler, küçük fonların büyük yatırımlara yönlendirilmesi, tasarruf sahiplerinin risklerinin azaltılması, projeler hakkında bilgi toplama ve değerlendirme maliyetlerinin uzmanlaşmış birimler kanalıyla düşürülmesi ve kaynakların etkin şekilde yönetilmesini sağlayarak ekonomide verimliliği ve ekonomik büyümeyi desteklemektedir (Aslan ve Küçükaksoy, 2006: 26).

Levine (1997), finansal sistemin ve finansal gelişmişlik düzeyinin makroekonomik etkilerini finansal piyasaların ve aracıların fonksiyonlarından hareketle beş başlıkta toplamaktadır. Levine (1997) 'e göre finansal sistemin fonksiyonları aşağıda sıralanmıştır:

-Risk yönetimini kolaylaştırma (amelioration): finansal piyasalar ve kurumlar, finansal varlıkların ticaretini kolaylaştırır, risklerin çeşitlendirilmesi ve birleştirilmesini sağlar,

-Yatırım fırsatları ile ilgili bilgi edinmeyi kolaylaştırma ve kaynakların daha etkin dağılımını sağlama,

- Bilgi edinme maliyetlerini azaltarak firma yöneticilerinin izlenmesini ve sermayenin kurumsal kontrolünü sağlama,

-Dağınık tasarrufların yatırım için organizasyonu ve üretim teknolojisinin temerküzünü sağlama,

•İşlem maliyetlerini azaltarak mal, hizmet ve sözleşme ticaretini kolaylaştırma.

Levine' in, bilgi edinme maliyetlerinin azaltılması ile firma yöneticilerinin izlenmesini ve sermayenin kurumsal kontrolünü sağlama şeklinde ifade ettiği finansal piyasa fonksiyonu, Capasso (2003) tarafından asimetrik bilgiyi ve bunun kaynak dağılımı üzerinde olumsuz etkilerini azaltma şeklinde ifade edilmiştir.

Finansal gelişim kavramı, bazı çalışmalarda finansal piyasalarda kullanılan ürünler ve finansal araçların artışı ve daha yaygın şekilde kullanılmaya başlaması, böylece finansal piyasaların gelişerek daha aktif hale gelmesi olarak ifade edilirken; bazı çalışmalarda ise finansal sistemin hacim, finansal kurumların ise yapı olarak büyümesi şeklinde ele alınmaktadır.

Daha genel bir tanım olarak finansal gelişim, finansal piyasalarda faaliyette bulunan kurumların sayılarının artması, finansal araçların çeşitliliklerinin çoğalması ve yaygınlaşması, finansal piyasaların derinleşmesi ve bunlara bağlı olarak finansal piyasaların temel fonksiyonu olan fon aktarımının etkin şekilde yerine getirilmesidir (Koç vd., 2016: 300). Finansal piyasalarda de-regülasyon (serbestleşme) süreci ve finansal yeniliklerin (inovasyonlar) uygulanması da finansal gelişimi olumlu şekilde etkileyen etmenlerdir. 
Huang’a göre (2005), ülkelerin finansal gelişmişlik seviyelerini o ülkelerin kurumsal yapıları, ülkelerin bulunduğu coğrafi bölgeler, uyguladıkları makroekonomik politikalar, ülke vatandaşlarının gelir seviyeleri ve kültürel yapıları gibi birçok faktör etkilemektedir.

Finansal gelişme bilginin yayılmasını sağlayarak bilgi asimetrisinin azılmasına ve dolayısıyla daha optimal finansal sözleşmelerin yapılmasına olanak sağlamaktadır. Daha optimal finansal sözleşmeler, izleme maliyetlerini azaltarak kaynakların daha etkin kullanımı ile yeniden dağılımını sağlamakta, sermaye birikiminde artışa neden olmakta ve ekonomik büyümeyi desteklemektedir (Capasso, 2003: 8).

Finansal piyasalar ve ekonomik büyüme arasındaki ilişki uzun zamandır incelenen bir konu olmuştur. Finansal piyasalar ve ekonomik büyüme arasındaki ilişkiye yönelik ilk bakış açısı, aktif bir finansal sistemin yeni yatırımları etkin bir şekilde finanse edeceği, bu şekilde yeni teknolojilerin ve üretim biçimlerinin gelişmesine katkı sağlayacağı şeklindedir. Bu yaklaşım arz öncüllü hipotez olarak adlandırılmaktadır. Bu yaklaşıma göre gelişmiş bir finansal sistem sermaye birikimini artırarak, üretim ve teknolojik ilerlemeleri finanse edecek fonlara ulaşımı ve temini kolaylaştıracak, böylece ekonomik büyümeyi olumlu etkileyecektir (Aydın vd., 2014).

Diğer bir yaklaşım ise, talep takipli hipotez olarak adlandırılan yaklaşımdır. Bu yaklaşıma göre ise ekonomik büyüme finansal sistemin gelişimine katkı sağlamaktadır. Reel sektörün büyüme ihtiyaçları yeni finansman talebi yaratmakta, bu finansman talebinin karşılanabilmesi için de finansal sistemde değişimler meydana gelmekte, yeni kurumlar, araçlar ve hizmetler devreye girmektedir (Aydın vd., 2014).

Konu ile ilgili bir üçüncü yaklaşım ise gelişme safhası hipotezidir (Patrick, 1966). Bu yaklaşıma göre ekonomik büyüme sürecinin ilk aşamalarında finansal gelişim ekonomik büyümeyi etkilemekte, finansal hizmetler ve ürünlerdeki artışlar tasarrufları sistem içine çekerek fon sağlamakta ve böylece yatırımların finanse edilmesiyle arzın öncülük ettiği aşama ortaya çıkmaktadır. Daha sonraki süreçte ekonomik büyüme ve finansal gelişim devam etmekte, ancak finansal gelişimin büyümeye etkisi azalmakta ve talep takipli duruma dönüşmektedir (Öztürk vd., 2011).

Çalışmada incelenecek bir diğer konu insani gelişim kavramıdır. İnsani gelişim (kalkınma), ikinci dünya savaşı sonrasında daha çok ekonomik büyüme ile açıklanmaya çalışılmıştır. Birçok iktisatçı kişi başına GSYH’ nın (Gayri Safi Yurt İçi Hasıla) ülkeler arasındaki insani gelişmişlik düzeyini karşılaştırmada güvenilir bir gösterge olduğunu savunmuşlardır (Tüylüoğlu ve Karalı, 2005).

1980’li yıllardan itibaren bazı iktisatçılar GSYH' nın kalkınmayı ölçmede bazı eksiklikler barındırdığını düşünmüşlerdir. Aynı iktisatçılar, özellikle ekonomik faydanın dağıtılması, yoksulluk faktörü, beslenme yetersizlikleri, okur-yazarlık faktörü, kişisel özgürlükler ve güvenliğin sınırlandırılması gibi yaşam düzeyini düşüren unsurların yanında, GSYH ölçütünün tek başına yetersiz olduğunu öne sürmüşlerdir (Todaro, 1992). 
Günümüzde kalkınma, sadece ülkelerin ekonomik performansları ile açıklanabilen bir kavram olarak değil, aynı zamanda insanların yaşam seviyelerinin yükselmesini sağlayan etkenleri de dikkate alan bir kavram olarak değerlendirilmektedir. Ekonomik büyümenin yarattığı etkinin, uygun gelir dağılımının da sağlanarak insanların yaşam standartlarını artırması gerektiği savunulmaktadır. İnsanların yaşam seviyelerinin ölçülebilmesi için çeşitli araştırmalar gerçekleştirilmekte ve çeşitli insani kalkınma göstergeleri ve endeksleri oluşturulmaktadır.

Önceki çalışmalarda, daha çok ülkelerdeki finansal ve insani gelişmişlik ile büyüme arasındaki ilişkiler ele alınmıştır. Bu çalışmada ise farklı bir konu olarak, OECD ülkelerinde, finansal gelişme ve insani gelişme ile ülkelerin sigortacılık toplam prim üretimleri arasındaki ilişki incelenmiştir. 2009 - 2016 yıllarını kapsayan dönemde, 34 OECD ülkesine ilişkin verilere eksiksiz bir şekilde ulaşılabilmiştir. Çalışmaya bu ülkeler dâhil edilmiş olup, finansal gelişmişlik değişkeni olarak IMF tarafından hesaplanmaya başlayan Finansal Gelişme Endeksi (FDI), insani gelişmişlik değişkeni olarak Birleşmiş Milletler tarafından hesaplanan İnsani Gelişme Endeksi (HDI) verileri kullanılmıştır.

Çalışmanın ilerleyen bölümlerinde, finansal gelişim ve insani gelişimin ölçülmesine yönelik süreçler anlatılmış, literatüre yer verilmiş, gerçekleştirilen analizlere ilişkin bulgular ortaya konmuş ve sonuçlar aktarılmıştır.

\section{FİNANSAL GELIŞIMİN ÖLÇÜLMESİ VE FİNANSAL GELIŞME ENDEKSİ}

Literatürdeki çalışmalarda finansal gelişimi temsilen değişik ölçütler kullanılmaktadır. Gerçekleştirilen ilk çalışmalarda finansal gelişmişliği ölçmede Yurtiçi Krediler / Gayrisafi Yurt İçi Hasıla (GSYH) veya Yurtiçi Krediler / Gayrisafi Milli Hasıla (GSMH) oranları ile Özel Sektör Kredileri / GSYH veya Özel Sektör Kredileri / GSMH oranları kullanılmıştır. Finansal derinliğin ölçülmesi içinse M2 para arzının GSYH veya GSMH' ya oranları kullanılmıştır. $\mathrm{Bu}$ ölçütlerin dışında, para piyasalarının etkinliğini ölçmede Toplam Mevduatlar / GSYH oranı, sermaye piyasalarının etkinliğini ölçmede sermaye piyasası işlem hacimleri, Sermaye Piyasası İşlem Hacmi / GSYH oranı, Piyasa Kapitalizasyonu / GSYH oranı gibi değişkenler temel alınmıștır. Ayrıca bu değişkenler ile faiz oranı, M1, M2, M3 para arzları ve/veya bunların GSYH' ya oranları gibi farklı değişkenleri baz alarak temel bileşenler analizleri ile oluşturulan endeksler de çeşitli çalışmalarda finansal gelişimi ölçmek amacıyla kullanılmıştır (Armutçuoğlu Tekin ve Ural, 2019).

2010 Yılı Dünya Ekonomik Formu Finansal Gelişme Raporunda, 57 ülke için Finansal Gelişme Endeksi (FDI) yayımlanmıştır (Arora, 2012: 188). Finansal gelişmeyi temsilen tek bir gösterge eksikliğini gidermek amacıyla, 2016 yılında Uluslararası Para Fonu (IMF) tarafından finansal kurumlar ve finansal piyasalar için derinlik, erişim ve etkinlik açısından sağlanan verilerden Finansal Gelişme Endeksi (FDI) oluşturulmuştur. FDI, 183 ülke için 1980 yılı başlangıç alınarak yıllık olarak hesaplanmıştır (Şenol, 2019: 344). 


\section{Şekil 1. Finansal Gelişme Endeksi Bileșenleri}

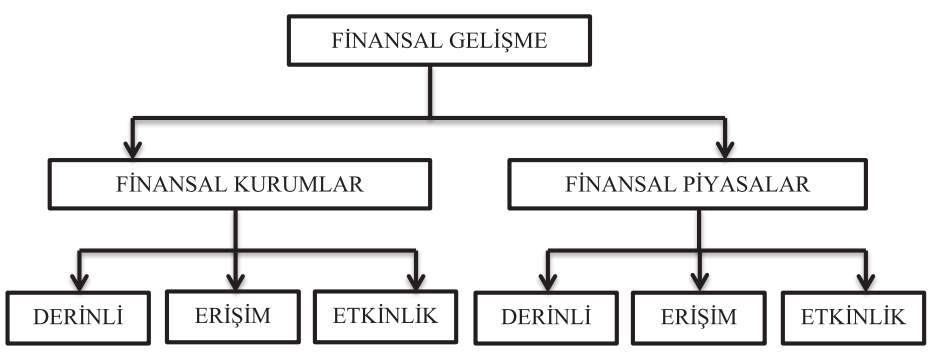

Kaynak: Svirydzenka, 2016: 5

Tablo 1. Finansal Gelişme Endeksi Hesaplamasında Kullanılan Değişkenler

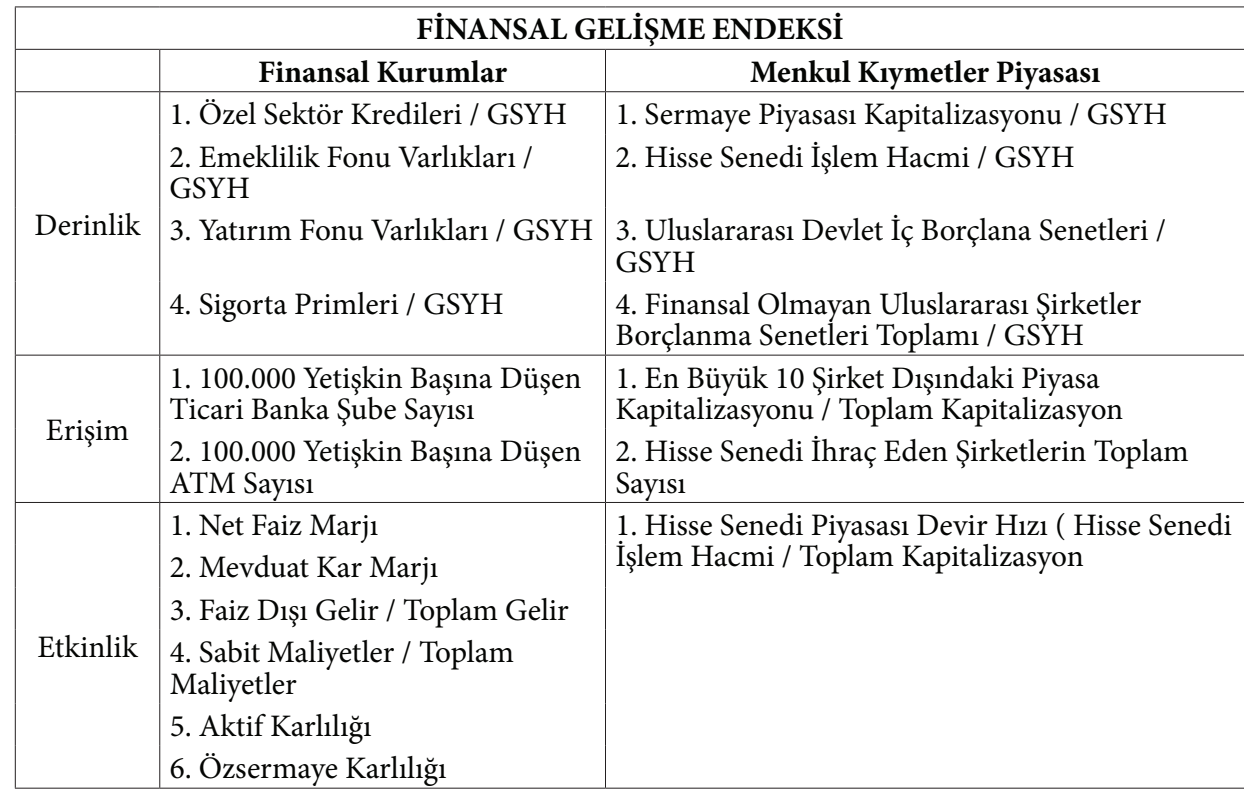

Kaynak: Sahay vd., 2015: 34

FDI' de finansal kurumlar; bankalar, sigorta şirketleri, yatırım fonları ve emeklilik fonlarından oluşurken, finansal piyasalar; pay ve borçlanma araçları piyasalarından oluşmaktadır. Finansal gelişme derinlik, erişim ve etkinlik şeklinde tanımlanmaktadır. Derinlik, piyasaların büyüklügünü ve likiditesini; erişim, bireylerin ve şirketlerin finansal hizmetlere ulaşabilmesini; etkinlik ise, finansal kurumların düşük maliyet ve sürdürülebilir gelirle finansal hizmetleri sağlama yeteneği ile finansal piyasa faaliyetlerinin seviyesini ifade etmektedir (Şenol, 2019: 344). 
$\mathrm{Bu}$ endeks temel bileşenler analizi yöntemi ile IMF tarafından hazırlanmakta olup, her bir gösterge 0 ile 1 arasında normalleştirilmiştir. Ani değișimleri engellemek adına veriler \% 95 güven aralığında düzenlenmiştir. "1" değeri en yüksek finansal gelişme düzeyi, "0" değeri ise en düşük finansal gelişme düzeyini temsil etmektedir (Sahay vd. 2015: 35).

Aşağıdaki tabloda 34 OECD ülkesinin 2016 yılına ait Finansal Gelişme Endeksi (FDI) değerleri ve Toplam Prim Üretimi / GSYH (TGP / GDP) oranları yer almaktadır. Genellikle yüksek FDI değerine sahip ülkelerde toplam prim üretiminin gayri safi yurtiçi hasıla içindeki payının da yüksek olduğu görülmektedir.

Tablo 2. OECD Ülkeleri 2016 Yılı Finansal Gelişme Endeksi (FDI) ve Toplam Prim Üretimi / GSYH (TGP / GDP)

\begin{tabular}{|l|l|l|l|l|l|}
\hline \multicolumn{1}{|c|}{ ÜLKE } & \multicolumn{1}{|c|}{$\begin{array}{l}\text { TPÜ / GSYH } \\
(\text { TGP / GDP) }\end{array}$} & FGE (FDI) & \multicolumn{1}{c|}{ ÜLKE } & $\begin{array}{l}\text { TPÜ / GSYH } \\
(\text { TGP / GDP) }\end{array}$ & FGE (FDI) \\
\hline Avustralya & 0,0614 & 0,854 & Letonya & 0,0213 & 0,291 \\
\hline Belçika & 0,0647 & 0,580 & Litvanya & 0,0183 & 0,257 \\
\hline Kanada & 0,0532 & 0,862 & Lüksemburg & 0,3439 & 0,746 \\
\hline Şili & 0,0496 & 0,467 & Meksika & 0,0224 & 0,409 \\
\hline Çek Cumhuriyeti & 0,0308 & 0,368 & Hollanda & 0,0987 & 0,706 \\
\hline Estonya & 0,0340 & 0,329 & Yeni Zelanda & 0,0251 & 0,605 \\
\hline Finlandiya & 0,0419 & 0,663 & Norveç & 0,0544 & 0,691 \\
\hline Fransa & 0,1274 & 0,765 & Polonya & 0,0301 & 0,474 \\
\hline Almanya & 0,0842 & 0,698 & Portekiz & 0,0585 & 0,691 \\
\hline Yunanistan & 0,0200 & 0,539 & Slovak Cumhuriyeti & 0,0301 & 0,324 \\
\hline Macaristan & 0,0250 & 0,436 & Slovenya & 0,0540 & 0,385 \\
\hline İzlanda & 0,0235 & 0,543 & İspanya & 0,0595 & 0,881 \\
\hline İrlanda & 0,1791 & 0,691 & İsveç & 0,0764 & 0,715 \\
\hline İsrail & 0,0474 & 0,568 & İsviçre & 0,1007 & 0,937 \\
\hline İtalya & 0,0810 & 0,801 & Türkiye & 0,0159 & 0,503 \\
\hline Japonya & 0,0878 & 0,868 & Birleşik Krallı & 0,1518 & 0,824 \\
\hline Güney Kore & 0,1312 & 0,855 & ABD & 0,1445 & 0,874 \\
\hline
\end{tabular}

Kaynak: IMF, OECD, Dünya Bankası

\section{2. İNSANİ GELIŞiIMİN ÖLÇÜLMESİ VE İNSANİ GELIŞME ENDEKSİ}

Günümüzdeki kalkınma kavramından yola çıkarak, insani gelişmişliğin ölçülmesi ile ilgili belirli çalışmalar yapılmıştır. Birleşmiş Milletler Sosyal Kalkınma Araştırma Enstitüsü (United Nations Research Institute on Social Development), 1960'lı ve 1970'li y1llarda gelişmekte olan birçok ülke için 9'u sosyal, 7'si iktisadi olan 16 temel gösterge ile bileşik bir endeks formülü kullanarak bir dizi çalışma yapmıştır. Washington'da Denizaşırı Kalkınma Konseyi (Overseas Development Council) tarafından 1970 ile 1980 yılları için 
Fiziksel Yaşam Kalite Endeksi oluşturulmuştur. Bu çalışmadaki temel göstergeler bebek ölüm oranı, yaşam beklentisi ve yetişkin okur/yazarlık oranıdır (Zortuk ve Ebeoğlugil, 2016: 384).

İnsani kalkınmanın sadece ekonomik göstergelerle ifade edilemeyeceği, yaşam kalitesinin belirlenmesinde farklı göstergelere de ihtiyaç duyulduğu gerçeğinden yola çıkarak Birleşmiş Milletler Kalkınma Programı (UNDP) öncülüğünde iktisatçı Mahbub U1 Haq, nobel ödüllü Amartya Sen ve birçok düşünce insani ve akademisyenin öncülüğünde ilk uluslararası gösterge niteliği taşıyan İnsani Gelişme Endeksi (HDI) geliştirilmiştir (UNDP, 1996).

HDI hesaplama yöntemi gelir, sağlık ve eğitim olmak üzere üç boyutta incelenmektedir.

\section{Şekil 2. İnsani Gelişme Endeksi Bileşenleri}

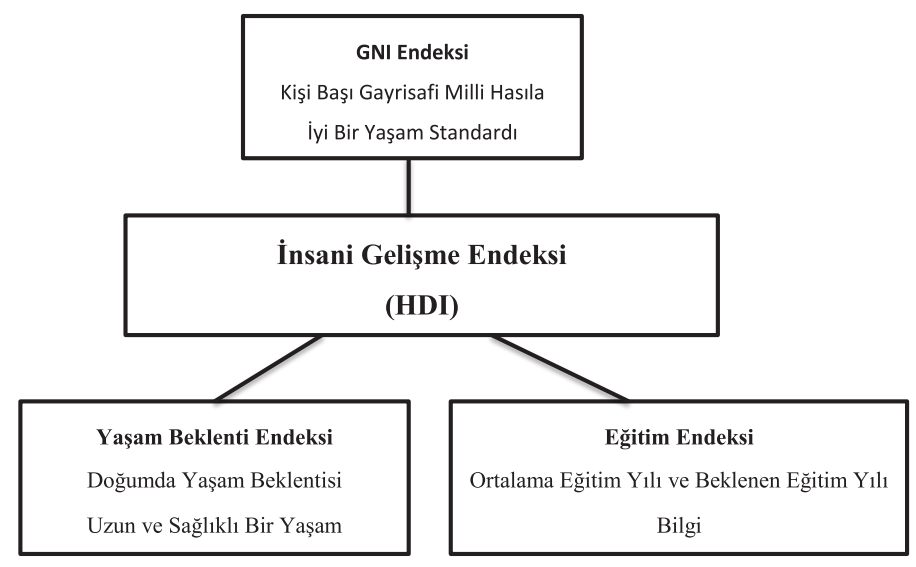

Kaynak: Sahay vd., 2015: 34

HDI hesaplanmasındaki üç faktör aşağıdaki şekilde ölçülmektedir (UNDP, 2010):

- Eğitim boyutu = 25 yaş ve üzeri kişilerin hayatı boyunca aldıkları eğitim yıllarının ortalaması olan yetişkin eğitiminin ortalama okullaşma yılı ve okula başlama yaşındaki çocukların beklenen okullaşma yılı göstergeleri ile ölçülmektedir.

- Sağlık Boyutu = Ölçümü ortalama yaşam süresi ile yapılır.

- Gelir Boyutu = Ölçümü kişi başına düşen gelirin satın alma gücü paritesi (PPP) ile hesaplanmasiyla yapılır. 
İnsani Gelişme Endeksinde 0-0,25 arası değerler düşük, 0,25-0,50 arası değerler orta, 0,500,75 arası değerler yüksek, 0,75 - 1 arası değerler çok yüksek insani gelişmişlik düzeyini ifade etmektedir. Ancak HDI değerleri incelenirken üzerinde durulması gereken nokta ülkelerin endeks değerlerinin ileriye mi yoksa geriye mi doğru hareket ettiğidir. Aşağıdaki tabloda 34 OECD ülkesinin 2016 yılına ait insani gelişme endeksi (HDI) değerleri ve toplam prim üretimi / gayri safi yurtiçi hasıla (TGP / GDP) oranları yer almaktadır.

Tablo 3. OECD Ülkeleri 2016 Yılı İnsani Gelişme Endeksi (HDI) ve Toplam Prim Üretimi / GSYH (TGP / GDP)

\begin{tabular}{|l|l|l|l|l|l|}
\hline \multicolumn{1}{|c|}{ ÜLKE } & $\begin{array}{l}\text { TPÜ / GSYH } \\
\text { (TGP / GDP) }\end{array}$ & İGE (HDI) & \multicolumn{1}{|c|}{ ÜLKE } & $\begin{array}{l}\text { TPÜ / GSYH } \\
(\text { TGP / GDP) }\end{array}$ & İGE (HDI) \\
\hline Avustralya & 0,0614 & 0,938 & Letonya & 0,0213 & 0,844 \\
\hline Belçika & 0,0647 & 0,915 & Litvanya & 0,0183 & 0,855 \\
\hline Kanada & 0,0532 & 0,922 & Lüksemburg & 0,3439 & 0,903 \\
\hline Şili & 0,0496 & 0,842 & Meksika & 0,0224 & 0,772 \\
\hline Çek Cumhuriyeti & 0,0308 & 0,885 & Hollanda & 0,0987 & 0,928 \\
\hline Estonya & 0,0340 & 0,868 & Yeni Zelanda & 0,0251 & 0,915 \\
\hline Finlandiya & 0,0419 & 0,918 & Norveç & 0,0544 & 0,951 \\
\hline Fransa & 0,1274 & 0,899 & Polonya & 0,0301 & 0,860 \\
\hline Almanya & 0,0842 & 0,934 & Portekiz & 0,0585 & 0,845 \\
\hline Yunanistan & 0,0200 & 0,868 & Slovak Cumhuriyeti & 0,0301 & 0,853 \\
\hline Macaristan & 0,0250 & 0,835 & Slovenya & 0,0540 & 0,894 \\
\hline İzlanda & 0,0235 & 0,933 & İspanya & 0,0595 & 0,889 \\
\hline İlanda & 0,1791 & 0,934 & İsveç & 0,0764 & 0,932 \\
\hline İsrail & 0,0474 & 0,902 & İsviçre & 0,1007 & 0,943 \\
\hline İtalya & 0,0810 & 0,878 & Türkiye & 0,0159 & 0,787 \\
\hline Japonya & 0,0878 & 0,907 & Birleşik Krallık & 0,1518 & 0,920 \\
\hline Güney Kore & 0,1312 & 0,900 & ABD & 0,1445 & 0,922 \\
\hline
\end{tabular}

Kaynak: Birleşmiş Milletler, OECD, Dünya Bankası

\section{LITERATÜR}

Akademik literatürde çoğunlukla finansal gelişme ile büyüme arasındaki ilişkiler incelenmiştir. Diğer çalışmalar ise finansal gelişme ile insani gelişmişlik, yönetişim, doğrudan yatırımlar, vb. arasındaki ilişkileri inceleyen çalışmalardır.

"Finansal gelişmişlik ve büyüme” arasındaki ilişkileri inceleyen bazı çalışmalara aşağıda yer verilmiştir. 
Outreville (1999), çalışmasında HDI ve M2/GSYH değişkenlerini kullanmıştır. Çalışmada, finansal gelişmenin ekonomik büyüme ve insan sermayesi gelişimiyle pozitif yönde ilişkili olduğu, insan sermayesinin finansal gelişmişlik seviyesini açıklamada önemli olduğu belirlenmiștir.

Evans vd. (2002) insan sermayesi ile finansal gelişmişliğin ekonomik büyümeye etkisini, işgücü, fiziksel sermaye, insan sermayesi ve parasal faktörler kullanarak, 82 ülke örnekleminde, 1972-1992 döneminde panel veri analiziyle gerçekleştirmiştir. Elde edilen sonuçlarda; parasal faktörün büyüme için etkili olduğu, finansal piyasalar ile sermaye birikimi arasında ilişki bulunduğu, kredi ve insan sermayesinin büyümeye pozitif etki yaptığı gözlemlenmiştir.

Khan ve Qayyum (2007), 1961-2005 dönemi verilerini kullanarak Pakistan ekonomisi için finansal gelişmenin büyüme üzerindeki etkilerini ARDL yaklaşımı temelinde incelemişlerdir. Elde edilen bulgulara göre, reel gayrisafi yurtiçi hâsıla ile finansal gelişme arasında uzun dönemde bir nedensellik ilişkisi olduğu ortaya konulmuştur.

Saci ve Holden (2008), gelişmekte olan otuz ülkede finansal gelişmenin büyüme üzerindeki etkilerini 1988-2001 dönemi verilerini kullanarak panel veri yöntemi ile incelemişlerdir. Çalışma sonucunda gelişmiş finansal sisteme sahip ülkelerin daha hızlı büyüdüğü tespit edilmiştir.

Mercan ve Peker (2013) finansal gelişmenin ekonomik büyüme üzerindeki etkisini 19922010 dönemi aylık verilerini kullanarak Türkiye ekonomisi için incelemişlerdir. Sınır testi yaklaşımıyla elde ettikleri bulgulara göre değişkenler arasında eşbütünleşme tespit etmişlerdir.

Hindistan özelinde finansal gelişme ile büyüme arasındaki ilişkiyi incelemeye çalışan Murty ve Samantaraya (2014), temel bileşenler analizi üzerinden bu ülkeye özgü bir "finansal gelişme endeksi” oluşturmuşlardır. Endeks oluşturulurken finans piyasalarının gelişim süreci tarihsel olarak üç döneme ayrılmıştır: (1) 1950'li yılların başından itibaren bankacilık sektörü ülkenin finans piyasasına hâkimdir. İlk endeks, 1951-2011 dönemi için, bankacılık sektörünün gelişimini ölçen göstergelere dayanmaktadır. (2) 1980 sonrası dönemde sermaye piyasasında gözlenen hareketlenme dikkate alınarak ilk endekse Bombay Menkul Kıymetler Borsası piyasa oranı eklenmiştir. Böylece 1982- 2011 dönemi için ikinci bir endeks oluşturulmuştur. (3) Üçüncü endeks ise, sadece reform sonrası dönemi (19912012) kapsamaktadır. Bu endeks ise ikinci endekse verimlilik göstergeleri ilave edilerek oluşturulmuştur. Bulgular, reform sonrası dönemde ağırlıklı olarak büyümeden finansal gelişmeye doğru tek yönlü bir nedensellik ilişkisinin olduğunu göstermektedir.

Arıç (2014), Avrupa Birliği’nde ekonomik büyüme ve finansal gelişmişlik düzeyi arasındaki ilişkiyi panel veri yöntemiyle incelemiştir. 2004- 2012 dönemine ait verileri kullanarak yaptığı analizde, genel kabul görmüş teorinin aksine, özel sektör kredilerinin milli gelire oranının büyümeyi negatif etkilediğini göstermiş, bunun nedenini banka 
kredilerinin büyümeye ilişkin alanlarda kullanılmamış olmasına bağlamıştır. Diğer finansal değişkenler, piyasa kapitalizasyon ve para arzının (M2) milli gelire oranının ise büyüme oranını pozitif olarak etkilediği görülmüştür.

Helhel (2017) E7 olarak sınıflandırılan ülkelerde 2001 - 2013 dönemi için finansal gelişme ve ekonomik büyüme arasındaki ilişkiyi incelemiştir. Ekonomik büyümeyi temsilen GSYH oranını, finansal gelişme değişkenleri olarak da yurtiçi banka kredilerinin, geniş anlamda para arzının (M2) ve piyasa kapitalizasyon değerinin milli gelire oranlarını kullanmıştır. Bulgular nedensellik ilişkisinin büyümeden finansal gelişmeye doğru olduğunu göstermiş ve "talep takipli hipotez" in geçerli olduğunu ortaya koymuştur.

"Finansal gelişme ile diğer değişkenler" arasındaki ilişkileri inceleyen çalışmalar aşağıda sunulmuştur.

Hakeem ve Oluitan (2012) 1965-2005 döneminde Güney Afrika'da insan sermayesi ile finansal gelişme arasındaki ilişkiyi zaman serisi çalışmasıyla araştırmışlardır. Çalışmada insan sermayesini temsilen yaşam beklentisi ve okullaşma oranı, finansal gelişmişliği temsilen M2 ve M3 para arzlarının GSYH' ya oranı kullanılmıştır. Eşbütünleşme ve nedensellik testleri sonucunda finansal gelişmişlik ile insan sermayesi arasında zayıf ilişki bulunmuştur.

Arora (2012), gelişmekte olan 21 Asya ülkesi örnekleminde 2000-2010 dönemi için finansal gelişme ile insan sermayesi arasındaki ilişkiyi incelemiştir. Sonuçlar, finansal gelişme (M2/GDP) ile eğitim arasında negatif ilişkiyi, bankacılığa erişim ile eğitim arasında ise pozitif ilişkiyi ortaya koymuştur.

Zortuk ve Ebeoğlugil (2016) Çek Cumhuriyeti, Estonya, Letonya, Macaristan, Polonya, Romanya, Slovenya ve Türkiye'den oluşan seçilmiş 8 ülkeye ait 2001-2011 döneminde, euro cinsinden sigorta prim üretimleri ile insani kalkınma endeksi arasındaki ilişkiyi panel veri analizi ile incelemişlerdir. Elde edilen sonuçlarda, insani kalkınma endeksindeki artışların sigorta prim üretimlerinde artışa neden olduğu tespit edilmiştir.

Kaya (2017), 1986-2015 dönemini kapsayan verileri kullanarak Türkiye için finansal gelişmişlik ile insani gelişmişlik arasındaki ilişkiyi incelemiştir. Finansal gelişmişliği temsilen BİST 100 endeksi, insani gelişmişliği temsilen insani gelişme endeksi kullanılmıştır. Eşbütünleşme ve nedenselik analizleri neticesinde, değişkenlerin uzun dönemde birlikte hareket ettikleri, yani eşbütünleşik oldukları ve insani gelişme endeksinden finansal gelişmişliğe doğru bir nedenselliğin bulunduğu görülmüştür.

Sayılır vd. (2018) finansal gelişmişlik ile ülkelerin yönetişim düzeyleri arasındaki ilişkiyi incelemişlerdir. 2012 yılı Dünya Ekonomik Forumu’nda sunulan finansal gelişmişlik raporundaki ülkelere ait finansal gelişmişlik endeksi verileri ile Dünya Bankası́nın yayınladığı 2012 yılına ait yönetişim göstergelerini kullandıkları çalışmada yapısal eşitlik modeli uygulamışlardır. Çalışma sonucunda, yönetişim ile finansal gelişme arasında 
pozitif ilişki tespit etmişlerdir.

Çelik (2019) yaptığı çalışmada finansal gelişmişlik düzeyinin doğrudan yabancı yatırım girişleri üzerindeki etkisini araştırmıştır. Bu bağlamda, kırılgan beşli ülkeleri olan Brezilya, Endonezya, G. Afrika, Hindistan ve Türkiye 1981-2016 dönemi için panel veri yöntemiyle analiz edilmiştir. Modelde yer alan doğrudan yabancı yatırım girişleri (DYY) bağımlı, finansal gelişme (FG), gayri safi yurtiçi hasıla (GSYH) ve tüketici fiyat endeksi (ENF) ise bağımsız değişkenlerdir. Değişkenler arasındaki uzun dönem ilişkilerini tahmin etmek amacıyla Pedroni ve Westerlund panel eşbütünleşme testleri uygulanmış ve değişkenler arasında uzun dönem ilişkisinin mevcut olduğu anlaşılmıştır. Uzun dönem katsayıları tam değiştirilmiş en küçük kareler (FMOLS) modeli kullanılarak tahmin edilmiş ve finansal gelişme ile doğrudan yabancı yatırım girişleri arasında ilişki olduğu görülmüştür.

İnsani gelişmişlik ile ilgili yapılan bazı çalışmalar ise aşağıda yer almaktadır.

Ranis, Stewart ve Ramirez (2000) insani gelişme ve ekonomik büyüme arasındaki çift yönlü etkileşimi incelemişlerdir. Ekonomik büyümeden insani gelişmişliğe ve insani gelişmişlikten ekonomik büyümeye doğru ilişkilerin tespit edilmesi amacıyla 19601992 yılları arasındaki dönemde regresyon analizleri kullanılmıştır. Yaptıkları çalışma sonucunda, sağlık ve eğitim amaçlı gerçekleştirilen kamu harcamalarının ekonomik büyümeden insani gelişmeye doğru olan etkileşimde önemli olduğu ve çift yönlü anlamlı ilişkilerin bulunduğu görülmüştür. İnsani gelişmeden ekonomik büyümeye doğru olan etkileşimde ise en önemli değişkenlerin yatırım oranı ve gelir dağılımı olduğu tespit edilmiştir.

Akhmat, Zaman ve Shukui (2014) Bangladeş, Hindistan, Nepal, Pakistan ve Sri Lanka ülkelerinde ekonomik büyüme, finansal gelişim ve insani gelișim arasındaki ilişkileri incelemişlerdir. Çalışma sonucunda, finansal gelişim ve ekonomik büyüme ile insani gelişim arasında uzun dönemli bir ilişkinin olduğu görülmüştür.

Giri ve Sehrawat (2014), 1980-2012 dönemine ait yıllık verileri kullandıkları çalışmalarında Hindistan'da finansal gelişim göstergeleri ile insani gelişmişlik arasındaki uzun ve kısa dönemli ilişkileri araştırmışlardır. Çalışmada, değişkenler arasında uzun dönemli ilişkilerin bulunduğu görülmüş olup, granger testi sonuçlarında finansal gelişim göstergelerinden insani gelişme endeksine (HDI) doğru nedensellik ilişkisinin olduğu tespit edilmiştir.

Azam vd. (2015), 34 gelişmekte olan ülke örnekleminde doğrudan yabancı sermaye yatırımları(DYSY) ile insan sermayesi (okullaşma oranı) arasındaki ilişkiyi araştırmışlardır. 1981-2013 dönemine ait yapılan çalışmada elde edilen sonuçlar, DYSY ile insan sermayesi arasında pozitif ilişki olduğunu ve DYSY’ nın insan sermayesini pozitif yönde etkilediğini ortaya koymuştur.

Kuloğlu ve Ecevit (2017), 1991-2014 yılları arasında yüksek gelirli ülkelerde sağlık 
ile finansal göstergeler arasındaki nedensellik ilişkisini incelemişlerdir. İlk aşamada, değişkenlerden dizinler elde etmek için temel bileşenler analizi yöntemi kullanılmıştır. Elde edilen sonuçlara göre, sağlık gelişme endeksi finansal gelişme endeksinin granger nedeni olarak bulunmuştur.

Satrovic (2017), 1986-2015 yılları arasında Türkiye için finansal kalkınma ve insan sermayesi arasında uzun ve kısa dönemli ilişkiyi araştırmıştır. ARDL yaklaşımını kullandığ çalışmasında, finansal gelişmeyi temsilen geniş para arzı / GSYH ile likit borçlar / GSYH göstergeleri kullanılmıştır. Çalışma sonucunda, insan sermayesinin geniş para arzı ve likit borçları uzun ve kısa dönemde etkilediği görülmüştür.

\section{4. ÇALIŞMANIN VERİ SETİ, YÖNTEM VE BULGULAR}

\subsection{Veri Seti ve Yöntem}

Çalışmada verileri eksiksiz olarak temin edilebilen 34 OECD ülkesine ait 2009 - 2016 yılları arasındaki finansal gelişme endeksi (FDI) ve insani gelişme endeksi (HDI) ile bu ülkelere ait toplam prim üretimi / gayri safi yurtiçi hasıla (TGP / GDP) oranlarına ilişkin veriler kullanılmıştır. FDI verileri IMF veri tabanından, HDI verileri Birleşmiş Milletler veri tabanından, toplam prim üretimi (total gross premiums) verileri OECD veri tabanından ve gayri safi yurtiçi hasıla (GDP) verileri Dünya Bankası veri tabanından temin edilmiştir.

Toplam prim üretimi / gayri safi yurtiçi hasıla (TGP / GDP) oranı ülkeler bazında hesaplanmıştır. OECD ülkelerine ait toplam prim üretimi verileri 2009 yılından önce düzenli olarak temin edilemediği ve birçok eksik veri bulunduğu için çalışmada 2009 2016 dönemi incelenmiştir.

Değişkenler arasındaki ilişkiler eşbütünleşme ve nedensellik testleriyle analiz edilmiştir. Öncelikle verilere ilişkin panel data seti oluşturulmuş, birim kök testleri yapılmış ve verilerin aynı dereceden durağan olup olmadıkları incelenmiştir. Birim kök araştırması yapıldıktan sonra eşbütünleşme analizlerine geçilmiştir. Eşbütünleşme analizlerinden elde edilen sonuçlar doğrultusunda nedensellik testleri uygulanmıştır.

Panel veri analizinde birim kökün varlığını araştırmak için hem DF (Dickey-Fuller) hemde ADF (Augmented Dickey-Fuller) testleri panel veri analizi için genişletilmiştir. Panel veri analizinde birçok birim kök testi ADF testinin genişletilmesi temeline dayanmaktadır. Fakat panel veri analizinde söz konusu süreç zaman serisi analizindekinden daha komplekstir. Panel veri analizinde en önemli faktör heterojenliktir. Özellikle paneldeki her bir birey aynı özelliklere sahip olmamakta, yani hepsi durağan ya da durağan olmama (eşbütünleşik ya da eşbütünleşik olmama) açısından farklılıklar göstermektedir. Bazı paneller birim köke sahip bazıları değilken birim kök testinin yapılması durumu 
karmaşıklaştıracaktır (Yardımcıoğlu ve Gülmez, 2013: 128). Bu nedenle, çalışmada panel veri analizleri için geliştirilmiş Levin, Lin \& Chu, Im, Pesaran and Shin W-stat, ADF Fisher Chi-square ve PP - Fisher Chi-square durağanlık testleri kullanılmıştır.

Panel eşbütünleşme analizleri için Pedroni ve Kao testleri uygulanmıştır. Pedroni panel eşbütünleşme testi, eşbütünleşme vektöründeki heterojenliği dikkate almaktadır. Böylece dinamik ve sabit etkilerin panelin yatay kesitleri arasında farklı olmasına imkân verirken, aynı zamanda alternatif hipotez altında eşbütünleşik vektörün kesitler arasında farklılaşmasını da sağlamaktadır. Pedroni’nin önerdiği tüm testler elde edilen artıklar üzerine kurulmuştur (Pedroni, 1999; 656). Pedroni testi 11 istatistik sonucu üretmektedir. $\mathrm{Bu}$ test sonuçlarının olasılık değerleri bize eşbütünleşmeye ilişkin fikir vermektedir. Çalışmada farklı bir yöntemle eşbütünleşme ilişkisini teyit etmek amacıyla Kao eşbütünleşme testi de kullanılmıştır. Kao (1999) DF ve ADF testlerini kullanarak panel veri için bir eşbütünleşme testi sunmaktadır (Baltagi ve Bai, 2000: 13).

Eşbütünleşme testlerinden elde edilen sonuçlara göre VAR analizlerine geçilerek optimum gecikme uzunlukları belirlenmiş ve Granger Nedensellik testleri yapılmıştır. Tüm testlerin uygulanmasında EViews-9 programı kullanılmıştır.

\subsection{Bulgular}

\subsubsection{Değişkenlere İlişkin Birim-Kök Testleri}

Değişkenlere ilişkin öncelikle birim-kök test sonuçları incelenmiştir. Testlerde düzey olarak sirasıyla ${ }^{*}{ }^{* \star}$ ve $^{* * *}$ ifadeleri, \%1, \%5 ve \%10 anlamlılık derecelerini ifade etmektedir.

Değişkenlere ilişkin düzey değerlerde birim-kök test sonuçlarını incelediğimizde, bazı test sonuçlarında birim kök olduğu, bazı test sonuçlarında ise birim kök bulunmadığına ilişkin istatistikler görülmüştür. Levin, Lin \& Chu ve PP - Fisher Chi-square testleri tüm değişkenlerin sabitli ve sabitli trend modellerde düzey değerlerinde durağan olduğunu söylerken; Im, Pesaran and Shin W-stat testi ise değişkenlerin sabitli trend modellerde düzey değerlerinde durağan olmadığını söylemektedir. 
Tablo 4. Değişkenlere İlişkin Düzey Değerlerde Birim Kök Test Sonuçları

\begin{tabular}{|c|c|c|c|c|c|c|}
\hline \multirow[t]{2}{*}{ TGP / GDP } & \multicolumn{2}{|c|}{ HİÇBİRİ } & \multicolumn{2}{|c|}{ SABİTLİ } & \multicolumn{2}{|c|}{ SABİTLİ VE TREND } \\
\hline & İstatistik & Olasılık & İstatistik & Olasılık & İstatistik & Olasılık \\
\hline Levin, Lin \& Chu $t^{*}$ & $-1,401$ & ${ }^{* * *} 0.0806$ & $-7,811$ & ${ }^{\star} 0.0000$ & $-23,238$ & ${ }^{\star} 0.0000$ \\
\hline Im, Pesaran and Shin W-stat & & & $-0,513$ & 0.3038 & $-1,231$ & 0.1091 \\
\hline ADF - Fisher Chi-square & 62,841 & 0.6541 & 88,095 & $* * * 0.0512$ & 102,875 & ${ }^{\star} 0.0041$ \\
\hline PP - Fisher Chi-square & 65,974 & 0.5470 & 99,033 & ${ }^{\star} 0.0083$ & 152,136 & ${ }^{*} 0.0000$ \\
\hline \multirow{2}{*}{ FDI } & \multicolumn{2}{|c|}{ HİÇBİRİ } & & BİTLİ & \multicolumn{2}{|c|}{ SABİTLİ VE TREND } \\
\hline & İstatistik & Olasılık & İstatistik & Olasılık & İstatistik & Olasılık \\
\hline Levin, Lin \& Chu $t^{*}$ & $-0,527$ & 0.2992 & $-28,681$ & ${ }^{\star} 0.0000$ & $-13,451$ & ${ }^{\star} 0.0000$ \\
\hline Im, Pesaran and Shin W-stat & & & $-5,753$ & ${ }^{*} 0.0000$ & $-0,430$ & 0.3337 \\
\hline ADF - Fisher Chi-square & 83,315 & ${ }^{* * *} 0.0999$ & 133,613 & ${ }^{\star} 0.0000$ & 86,120 & ${ }^{* * *} 0.0681$ \\
\hline PP - Fisher Chi-square & 126,627 & ${ }^{\star} 0.0000$ & 156,723 & ${ }^{\star} 0.0000$ & 136,976 & ${ }^{\star} 0.0000$ \\
\hline \multirow[t]{2}{*}{ HDI } & \multicolumn{2}{|c|}{ HİÇBİRİ } & & BİTLİ & \multicolumn{2}{|c|}{ SABİTLİ VE TREND } \\
\hline & İstatistik & Olasılık & İstatistik & Olasılık & İstatistik & Olasılık \\
\hline Levin, Lin \& Chu $t^{*}$ & 19,044 & 1,000 & $-8,854$ & ${ }^{*} 0.0000$ & $-20,975$ & ${ }^{\star} 0.0000$ \\
\hline Im, Pesaran and Shin W-stat & & & 0,996 & 0.8403 & $-0,724$ & 0.2345 \\
\hline ADF - Fisher Chi-square & 2,807 & 1,000 & 72,199 & 0.3410 & 82,968 & 0.1046 \\
\hline PP - Fisher Chi-square & 0,779 & 1,000 & 122,803 & ${ }^{\star} 0.0001$ & 134,600 & ${ }^{*} 0.0000$ \\
\hline
\end{tabular}

Değişkenlerin birinci farklarına ilişkin birim-kök test sonuçlarına baktığımızda ise değişkenlerin tüm test değerlerinde durağan olduğu görülmektedir. Sadece Im, Pesaran and Shin W-stat testi sabitli trend modelde HDI değişkeninin durağan olmadığına ilişkin sonuç vermiştir. Ancak diğer tüm test değerleri değişkenin birinci farkında durağan olduğunu göstermektedir.

Birim-kök test sonuçlarında değişkenlerin benzer düzeyde durağan olduğu görülmektedir. Değişkenlerin düzey değerlerinde, benzer testlerde benzer sonuçlar görülmüş, birinci farklarında ise, durağan olduklarına ilişkin aynı sonuçlar elde edilmiştir. HDI değişkenin birinci fark değerlerinde de, bir test hariç diğer tüm testler durağan olduğunu göstermiştir. 
Tablo 5. Değişkenlere İlişkin Birinci Fark Değerlerde Birim Kök Test Sonuçları

\begin{tabular}{|c|c|c|c|c|c|c|}
\hline \multirow[t]{2}{*}{ TGP / GDP } & \multicolumn{2}{|c|}{ HİÇBİRİ } & \multicolumn{2}{|c|}{ SABİTLİ } & \multicolumn{2}{|c|}{ SABİTLİ VE TREND } \\
\hline & İstatistik & Olasılık & İstatistik & Olasılık & İstatistik & Olasılık \\
\hline Levin, Lin \& Chu $t^{*}$ & $-15,398$ & ${ }^{*} 0.0000$ & $-22,999$ & ${ }^{*} 0.0000$ & $-18,624$ & ${ }^{\star} 0.0000$ \\
\hline Im, Pesaran and Shin W-stat & & & $-7,000$ & ${ }^{*} 0.0000$ & $-1,355$ & ${ }^{* * *} \mathbf{0 . 0 8 7 7}$ \\
\hline ADF - Fisher Chi-square & 261,465 & ${ }^{\star} 0.0000$ & 178,145 & ${ }^{\star} 0.0000$ & 114,851 & ${ }^{*} 0.0003$ \\
\hline PP - Fisher Chi-square & 279,615 & ${ }^{\star} 0.0000$ & 220,200 & ${ }^{*} 0.0000$ & 210,968 & ${ }^{\star} 0.0000$ \\
\hline \multirow[t]{2}{*}{ FDI } & \multicolumn{2}{|c|}{ HİÇBİRİ } & \multicolumn{2}{|c|}{ SABİTLİ } & \multicolumn{2}{|c|}{ SABİTLİ VE TREND } \\
\hline & İstatistik & Olasılık & İstatistik & Olasılık & İstatistik & Olasılık \\
\hline Levin, Lin \& Chu $t^{*}$ & $-17,392$ & ${ }^{\star} 0.0000$ & $-20,448$ & ${ }^{\star} 0.0000$ & $-29,993$ & ${ }^{\star} 0.0000$ \\
\hline Im, Pesaran and Shin W-stat & & & $-6,428$ & ${ }^{\star} 0.0000$ & $-2,696$ & ${ }^{\star} 0.0035$ \\
\hline ADF - Fisher Chi-square & 298,674 & ${ }^{\star} 0.0000$ & 168,633 & ${ }^{*} 0.0000$ & 137,387 & ${ }^{\star} 0.0000$ \\
\hline PP - Fisher Chi-square & 319,425 & ${ }^{\star} 0.0000$ & 209,552 & ${ }^{\star} 0.0000$ & 205,408 & ${ }^{\star} 0.0000$ \\
\hline \multirow[t]{2}{*}{ HDI } & \multicolumn{2}{|c|}{ HİÇBİRİ } & \multicolumn{2}{|c|}{ SABİTLİ } & \multicolumn{2}{|c|}{ SABİTLİ VE TREND } \\
\hline & İstatistik & Olasılık & İstatistik & Olasılık & İstatistik & Olasılık \\
\hline Levin, Lin \& Chu $\mathrm{t}^{*}$ & $-8,438$ & ${ }^{\star} 0.0000$ & $-21,902$ & ${ }^{\star} 0.0000$ & $-19,061$ & ${ }^{\star} \mathbf{0 . 0 0 0 0}$ \\
\hline Im, Pesaran and Shin W-stat & & & $-5,544$ & ${ }^{\star} 0.0000$ & $-0,893$ & 0.1858 \\
\hline ADF - Fisher Chi-square & 146,787 & ${ }^{\star} 0.0000$ & 151,099 & ${ }^{\star} 0.0000$ & 95,549 & ${ }^{\star *} 0.0155$ \\
\hline PP - Fisher Chi-square & 156,098 & ${ }^{\star} 0.0000$ & 189,287 & ${ }^{\star} 0.0000$ & 168,332 & ${ }^{\star} 0.0000$ \\
\hline
\end{tabular}

\subsubsection{TGP/GDP ile FDI Arasındaki Eşbütünleșme ve Nedensellik Analizleri}

Birim-kök testlerinin ardından TGP / GDP ile FDI arasındaki ilişkiyi incelemek üzere Pedroni ve Kao eşbütünleşme analizlerine geçilmiştir. Pedroni eşbütünleşme analizleri; bireysel sabitli testler, bireysel sabitli ve bireysel trend testler ile hiçbir sabit ve trend olmayan testler olmak üzere üç farklı şekilde incelenmiştir. Testlerde düzey olarak sırasıyla ${ }^{\star},{ }^{* *}$ ve ${ }^{* * *}$ ifadeleri, $\% 1, \% 5$ ve $\% 10$ anlamlılık derecelerini ifade etmektedir.

Hiçbir sabit ve trend olmayan testlere ilişkin Pedroni eşbütünleşme analizleri incelendiğinde, 11 test istatistiğinden 8 ' inde eşbütünleşmenin olduğuna ilişkin bulgular elde edilmiştir.

Bireysel sabitli testlere ilişkin Pedroni eşbütünleşme analizleri incelendiğinde, 11 test istatistiğinden 8' inde eşbütünleşmenin olduğuna ilişkin bulgular elde edilmiştir.

Bireysel sabitli ve bireysel trend testlere ilişkin Pedroni eşbütünleşme testleri sonucunda 11 istatistikten 7'sinde eşbütünleşmeye ilişkin sonuçlar görülmüştür. 
Tablo 6. TGP / GDP ile FDI Pedroni Eşbütünleşme Analizi Sonuçları

\begin{tabular}{|c|c|c|c|c|c|c|}
\hline Pedroni Eşbütünleşme & \multicolumn{6}{|c|}{ TGP/GDP - FDI } \\
\hline & \multicolumn{2}{|c|}{ Hiçbiri } & \multicolumn{2}{|c|}{ Bireysel Sabitler } & \multicolumn{2}{|c|}{$\begin{array}{c}\text { Bireysel Sabitler ve } \\
\text { Bireysel Trend }\end{array}$} \\
\hline & İstatistik & Olasılık & İstatistik & Olasılık & İstatistik & Olasılık \\
\hline Panel v-Statistic & 4,4917 & ${ }^{\star} 0.0000$ & 3,5808 & ${ }^{*} 0.0002$ & $-2,3322$ & 0.9902 \\
\hline Panel rho-Statistic & $-6,3126$ & ${ }^{\star} 0.0000$ & $-5,2923$ & ${ }^{*} 0.0000$ & $-1,4755$ & $* * * 0.0700$ \\
\hline Panel PP-Statistic & $-10,1417$ & ${ }^{*} 0.0000$ & $-14,2759$ & ${ }^{\star} \mathbf{0 . 0 0 0 0}$ & $-19,7696$ & ${ }^{\star} 0.0000$ \\
\hline \multirow[t]{2}{*}{ Panel ADF-Statistic } & $-10,2005$ & ${ }^{\star} 0.0000$ & $-14,0697$ & ${ }^{\star} 0.0000$ & $-18,9876$ & ${ }^{\star} 0.0000$ \\
\hline & $\begin{array}{l}\text { Ağırlıklı } \\
\text { İstatistik }\end{array}$ & Olasılık & $\begin{array}{l}\text { Ağırlıklı } \\
\text { İstatistik }\end{array}$ & Olasılık & $\begin{array}{l}\text { Ağırlıklı } \\
\text { İstatistik }\end{array}$ & Olasılık \\
\hline Panel v-Statistic & $-2,0045$ & 0.9775 & 0,2565 & 0.3988 & $-3,0146$ & 0.9987 \\
\hline Panel rho-Statistic & $-0,7536$ & 0.2255 & $-0,1068$ & 0.4575 & 2,5923 & 0.9952 \\
\hline Panel PP-Statistic & $-2,4139$ & ${ }^{\star} 0.0079$ & $-4,2234$ & ${ }^{\star} 0.0000$ & $-8,7758$ & ${ }^{\star} 0.0000$ \\
\hline \multirow[t]{2}{*}{ Panel ADF-Statistic } & $-4,3387$ & ${ }^{\star} 0.0000$ & $-4,4476$ & ${ }^{\star} 0.0000$ & $-7,1629$ & ${ }^{\star} 0.0000$ \\
\hline & İstatistik & Olasılık & İstatistik & Olasılık & İstatistik & Olasılık \\
\hline Group rho-Statistic & 1,9342 & 0.9735 & 2,1871 & 0.9856 & 4,2507 & 1.000 \\
\hline Group PP-Statistic & $-3,8254$ & ${ }^{*} 0.0001$ & $-5,8010$ & ${ }^{*} 0.0000$ & $-10,3869$ & ${ }^{\star} 0.0000$ \\
\hline Group ADF-Statistic & $-6,1235$ & ${ }^{*} 0.0000$ & $-4,8132$ & ${ }^{\star} 0.0000$ & $-8,9702$ & ${ }^{*} 0.0000$ \\
\hline
\end{tabular}

Pedroni testleri sonrasında, Kao eşbütünleşme analizi yapılarak bir başka yöntemle eşbütünleşmeye ilişkin bulgular tekrar incelenmiştir. Kao testi sonucunda da alternatif hipotez reddedilmiş ve eşbütünleşmenin olduğu yönünde bulgu elde edilmiştir.

Tablo 7. TGP / GDP ile FDI Kao Eşbütünleşme Test Sonucu

\begin{tabular}{|l|c|c|}
\hline \multicolumn{3}{|c|}{ Kao Eşbütünleşme Testi } \\
\hline \multicolumn{3}{|c|}{ TGP/GDP - FDI } \\
\hline & İstatistik & Olasılık \\
\hline ADF & $-10,7096$ & ${ }^{\star} \mathbf{0 . 0 0 0 0}$ \\
\hline & & \\
\hline Residual variance & 0.000341 & \\
\hline HAC variance & 0.000328 & \\
\hline
\end{tabular}

Eşbütünleşmeye ilişkin bulguların ardından VAR modeli oluşturulmuş ve optimum gecikme uzunluğu tespit edilmiştir.

Gecikme uzunluğunun tespitinde LR testi, Son Tahmin Hata Kriteri, Akaike, Schwarz ve 
Hannan-Quinn bilgi kriterleri kullanılmıştır. Beş kriterden dördünde optimum gecikme uzunluğu 2, sadece Schwarz kriterinde 1 olarak çıkmıştır. Bu sebeple, Granger nedensellik analizinde gecikme uzunluğu 2 olarak belirlenmiştir.

Tablo 8. TGP / GDP ile FDI VAR Analizi Gecikme Uzunluğu Tablosu

\begin{tabular}{|c|c|c|c|c|c|c|}
\hline \multicolumn{7}{|c|}{ VAR Gecikme Uzunluğu Kriterleri } \\
\hline \multicolumn{7}{|c|}{ İçsel Değişkenler: TGP/GDP - FDI } \\
\hline Gecikme & $\log L$ & LR & FPE & AIC & SC & HQ \\
\hline 0 & 114,1132 & NA & 0.000127 & $-3,2974$ & $-3,2322$ & $-3,2716$ \\
\hline 1 & 393,7635 & 534,6254 & $3.82 \mathrm{e}-08$ & $-11,4048$ & $-11,20897^{\star}$ & $-11,3272$ \\
\hline 2 & 399,8245 & $11,23084^{*}$ & $3.60 \mathrm{e}-08^{\star}$ & $-11,46543^{*}$ & $-11,1390$ & $-11,33610^{*}$ \\
\hline 3 & 403,5848 & 6,7463 & $3.63 \mathrm{e}-08$ & $-11,4584$ & $-11,0014$ & $-11,2773$ \\
\hline 4 & 407,5640 & 6,9051 & $3.63 \mathrm{e}-08$ & $-11,4578$ & $-10,8703$ & $-11,2250$ \\
\hline 5 & 411,7323 & 6,9880 & $3.63 \mathrm{e}-08$ & $-11,4627$ & $-10,7446$ & $-11,1782$ \\
\hline 6 & 414,7284 & 4,8466 & $3.75 \mathrm{e}-08$ & $-11,4332$ & $-10,5846$ & $-11,0969$ \\
\hline \multicolumn{7}{|c|}{${ }^{\star}$ Kriterlere göre seçilen gecikme uzunluğunu göstermektedir } \\
\hline \multicolumn{7}{|c|}{ LR: LR test istatistiği (her test 5\% düzeydedir) } \\
\hline \multicolumn{7}{|c|}{ FPE: Son tahmin hata kriteri } \\
\hline \multicolumn{7}{|c|}{ AIC: Akaike bilgi kriteri } \\
\hline \multicolumn{7}{|c|}{ SC: Schwarz bilgi kriteri } \\
\hline HQ: Han & han-Quinn & i kriteri & & & & \\
\hline
\end{tabular}

Granger nedensellik testi sonucunda \%5 anlamlılık düzeyinde, finansal gelişme endeksinden (FDI) toplam prim üretimi / gayri safi yurtiçi hasıla (TGP / GDP) oranına doğru nedensellik ilişkisi görülmüştür. OECD ülkelerinde finansal gelişme, toplam prim üretimi /gayri safi yurtiçi hasıla oranlarını etkilemektedir.

Tablo 9. TGP / GDP ile FDI Granger Nedensellik Analizi Sonuçları

\begin{tabular}{|l|l|l|}
\hline \multicolumn{3}{|c|}{ Pairwise Granger Nedensellik Testi } \\
\hline Örneklem: 2009 2016 & & \\
\hline Gecikme Uzunluğu: 2 & F İstatistiği & Olasıllk \\
\hline & & \\
\hline Boş Hipotez: & & ${ }^{* *} \mathbf{0 . 0 1 7 2}$ \\
\hline & 4,14541 & 0.9876 \\
\hline FDI Granger sebebi değildir - TGP/GDP & 0,01245 & \\
\hline TGP/GDP Granger sebebi değildir - FDI &
\end{tabular}




\subsubsection{TGP/GDP ile HDI Arasındaki Eşbütünleşme ve Nedensellik Analizleri}

TGP / GDP ile HDI arasındaki eşbütünleşme ilişkisini incelemek üzere öncelikle Pedroni ve Kao eşbütünleşme analizleri yapılmıştır.

Tablo 10. TGP / GDP ile HDI Pedroni Eşbütünleşme Analizi Sonuçları

\begin{tabular}{|c|c|c|c|c|c|c|}
\hline \multirow{3}{*}{$\begin{array}{c}\text { Pedroni } \\
\text { Eşbütünleşme Testi }\end{array}$} & \multicolumn{6}{|c|}{ TGP/GDP - HDI } \\
\hline & \multicolumn{2}{|c|}{ Hiçbiri } & \multicolumn{2}{|c|}{ Bireysel Sabitler } & \multicolumn{2}{|c|}{$\begin{array}{c}\text { Bireysel Sabitler ve } \\
\text { Bireysel Trend }\end{array}$} \\
\hline & İstatistik & Olasılık & İstatistik & Olasılık & İstatistik & Olasılık \\
\hline Panel v-Statistic & 2,3869 & ${ }^{\star} 0.0085$ & 0,0750 & 0.4701 & $-5,0427$ & 1,0000 \\
\hline Panel rho-Statistic & $-5,7878$ & ${ }^{*} 0.0000$ & $-5,1308$ & ${ }^{*} 0.0000$ & $-1,2207$ & 0.1111 \\
\hline Panel PP-Statistic & $-9,1574$ & ${ }^{\star} 0.0000$ & $-31,4310$ & ${ }^{*} 0.0000$ & $-41,1014$ & ${ }^{*} 0.0000$ \\
\hline \multirow[t]{2}{*}{ Panel ADF-Statistic } & $-9,4021$ & ${ }^{\star} 0.0000$ & $-21,1543$ & ${ }^{*} 0.0000$ & $-26,3706$ & ${ }^{*} 0.0000$ \\
\hline & $\begin{array}{l}\text { A ğ } 1 \text { rlıklı } \\
\text { İstatistik }\end{array}$ & Olasılık & $\begin{array}{l}\text { Ağ } 1 \text { rlıklı } \\
\text { İstatistik }\end{array}$ & Olasılık & $\begin{array}{l}\text { A ğ } 1 \mathrm{rl} 1 \mathrm{kl} 11 \\
\text { İstatistik }\end{array}$ & Olasılık \\
\hline Panel v-Statistic & $-0,8941$ & 0.8144 & 0,9256 & 0.1773 & $-3,6373$ & 0.9999 \\
\hline Panel rho-Statistic & $-1,0798$ & 0.1401 & $-1,5305$ & $* * * 0.0629$ & 2,3367 & 0.9903 \\
\hline Panel PP-Statistic & $-2,3950$ & ${ }^{\star} 0.0083$ & $-9,0681$ & ${ }^{*} 0.0000$ & $-9,1668$ & ${ }^{*} 0.0000$ \\
\hline \multirow[t]{2}{*}{ Panel ADF-Statistic } & $-3,5986$ & ${ }^{\star} 0.0002$ & $-8,3028$ & ${ }^{\star} 0.0000$ & $-7,6730$ & ${ }^{\star} 0.0000$ \\
\hline & İstatistik & Olasılık & İstatistik & Olasılık & İstatistik & Olasılık \\
\hline Group rho-Statistic & 2,1642 & 0.9848 & 1,0377 & 0.8503 & 4,5634 & 1,0000 \\
\hline Group PP-Statistic & $-3,7045$ & ${ }^{\star} 0.0001$ & $-11,5768$ & ${ }^{*} 0.0000$ & $-10,9463$ & ${ }^{\star} 0.0000$ \\
\hline Group ADF-Statistic & $-7,8588$ & ${ }^{\star} 0.0000$ & $-8,9159$ & ${ }^{*} 0.0000$ & $-7,1569$ & ${ }^{\star} 0.0000$ \\
\hline
\end{tabular}

Hiçbir sabit ve trend olmayan testlere ilişkin Pedroni eşbütünleşme analizleri incelendiğinde, 11 test istatistiğinden 8 ' inde eşbütünleşmenin olduğuna ilişkin bulgular elde edilmiştir.

TGP / GDP ile HDI arasındaki ilişkinin incelenmesi amacıyla, bireysel sabitli testlere ilişkin Pedroni eşbütünleşme analizleri incelendiğinde, 11 test istatistiğinden 8' inde eşbütünleşmenin olduğuna ilişkin bulgular elde edilmiştir.

Bireysel sabitli ve bireysel trend testlere ilişkin Pedroni eşbütünleşme analizleri sonucunda ise 11 istatistikten 6’sında eşbütünleşmeye ilişkin sonuçlar görülmüştür.

Pedroni testleri sonrasında, TGP / GDP ile HDI arasındaki eşbütünleşmeyi farklı bir yöntemle incelemek için Kao eşbütünleşme testi yapılmıştır. 
Tablo 11. TGP / GDP ile HDI Kao Eşbütünleşme Test Sonucu

\begin{tabular}{|l|c|c|}
\hline \multicolumn{3}{|c|}{ Kao Eşbütünleşme Testi } \\
\hline \multicolumn{3}{|c|}{ TGP/GDP - HDI } \\
\hline & İstatistik & Olasıllk \\
\hline ADF & $-10,7104$ & ${ }^{\star} \mathbf{0 . 0 0 0 0}$ \\
\hline & & \\
\hline Residual variance & 0.000343 & \\
\hline HAC variance & 0.000329 & \\
\hline
\end{tabular}

Kao testi sonucunda da alternatif hipotez reddedilmiş ve eşbütünleşmenin olduğu yönünde sonuç elde edilmiştir.

Eşbütünleşmeye ilişkin bulguların ardından VAR modeli oluşturulmuş ve optimum gecikme uzunlukları tespit edilmiştir. Gecikme uzunluğunun tespitinde LR testi, Son Tahmin Hata Kriteri, Akaike, Schwarz ve Hannan-Quinn bilgi kriterleri kullanılmıştır.

Tablo 12. TGP / GDP ile HDI VAR Analizi Gecikme Uzunluğu Tablosu

\begin{tabular}{|c|c|c|c|c|c|c|}
\hline \multicolumn{7}{|c|}{ VAR Gecikme Uzunluğu Kriterleri } \\
\hline \multicolumn{7}{|c|}{ İçsel Değişkenler: TGP/GDP - HDI } \\
\hline Lag & $\log L$ & LR & FPE & AIC & SC & HQ \\
\hline 0 & 212,7514 & NA & $6.97 e-06$ & $-6,1986$ & $-6,1333$ & $-6,1727$ \\
\hline 1 & 538,1300 & 622,0472 & $5.47 \mathrm{e}-10$ & $-15,6509$ & $-15,45504^{\star}$ & $-15,57328^{\star}$ \\
\hline 2 & 542,3768 & 7,8691 & $5.43 \mathrm{e}-10^{*}$ & $-15,65814^{\star}$ & $-15,3317$ & $-15,5288$ \\
\hline 3 & 543,6023 & 2,1986 & $5.90 \mathrm{e}-10$ & $-15,5765$ & $-15,1196$ & $-15,3955$ \\
\hline 4 & 550,2684 & $11,56766^{*}$ & $5.46 \mathrm{e}-10$ & $-15,6550$ & $-15,0674$ & $-15,4222$ \\
\hline 5 & 552,5913 & 3,8944 & $5.76 \mathrm{e}-10$ & $-15,6056$ & $-14,8876$ & $-15,3211$ \\
\hline 6 & 556,5586 & 6,4177 & $5.78 \mathrm{e}-10$ & $-15,6047$ & $-14,7560$ & $-15,2684$ \\
\hline \multicolumn{7}{|c|}{${ }^{*}$ Kriterlere göre seçilen gecikme uzunluğunu göstermektedir } \\
\hline \multicolumn{7}{|c|}{ LR: LR test istatistiği (her test $5 \%$ düzeydedir) } \\
\hline \multicolumn{7}{|c|}{ FPE: Son tahmin hata kriteri } \\
\hline \multicolumn{7}{|c|}{ AIC: Akaike bilgi kriteri } \\
\hline \multicolumn{7}{|c|}{ SC: Schwarz bilgi kriteri } \\
\hline \multicolumn{7}{|c|}{ HQ: Hannan-Quinn bilgi kriteri } \\
\hline
\end{tabular}

Gecikme uzunluğu, kriterlerin ikisinde (Schwarz ve Hannan-Quinn) 1, kriterlerin ikisinde (Son Tahmin Hata Kriteri ve Akaike) 2, sadece LR testi kriterinde 4 olarak çıkmıştır. 
Bu sebeple Granger nedensellik analizinde gecikme uzunluğu hem 1 hem de 2 olarak belirlenerek testler uygulanmıştır.

Tablo 13. TGP / GDP ile HDI Granger Nedensellik Analizi Sonuçları

\begin{tabular}{|c|c|c|}
\hline \multicolumn{3}{|c|}{ Pairwise Granger Nedensellik Testi } \\
\hline \multicolumn{3}{|l|}{ Örneklem: 20092016} \\
\hline \multicolumn{3}{|l|}{ Gecikme Uzunluğu: 1} \\
\hline Boş Hipotez: & F İstatistiği & Olasılık \\
\hline HDI Granger sebebi değildir - TGP/GDP & 1,98772 & 0.1599 \\
\hline TGP/GDP Granger sebebi değildir - HDI & 0,00807 & 0.9285 \\
\hline \multicolumn{3}{|l|}{ Gecikme Uzunluğu: 2} \\
\hline Boş Hipotez: & F İstatistiği & Olasılık \\
\hline HDI Granger sebebi değildir - TGP/GDP & 4,60535 & ${ }^{* *} 0.0111$ \\
\hline TGP/GDP Granger sebebi değildir - HDI & 0,23131 & 0.7937 \\
\hline
\end{tabular}

Granger nedensellik testi sonucunda, gecikme uzunluğunun 1 olarak alındığı test için pozitif sonuçlar elde edilememiş, ancak gecikme uzunluğunun 2 olarak alındığı test sonucunda \%5 anlamlılık düzeyinde, insani gelişme endeksinden (HDI) toplam prim üretimi / gayri safi yurtiçi hasıla (TGP / GDP) oranına doğru nedensellik ilişkisi tespit edilmiştir. OECD ülkelerinde insani gelişmişlik düzeyinin toplam prim üretimi /gayri safi yurtiçi hasıla oranlarını etkilediği görülmüştür.

\section{SONUÇ}

Finansal gelişim; fonların yatırımlara yönlendirilmesi, tasarruf sahiplerine alternatif yatırım imkânlarının sağlanması, finansal kurumlara daha kolay ulaşım sağlanması, işlem maliyetlerinin azaltılması, kaynakların etkin yönetimi gibi konularda ekonomiyi olumlu etkileyerek ekonomik gelişmeyi ve verimliliği desteklemektedir. İnsani gelişmişlik düzeyi ise günümüzde ekonomik göstergeler yanında bazı sosyolojik göstergelerin de birlikte ele alındığı bir kavramdır.

Gerek arz öncüllü hipotez, gerek talep takipli hipotez, gerekse gelişme safhası hipotezi açısından ekonomik büyüme ile finansal gelişim etkileşim içindedir. Etkileşim aşamaları 
farklı şekilde de olsa, finansal gelişimin getirdiği süreçte yeni finansal ürünler ve araçlar ile yeni teknolojiler hayata girmekte; finansal piyasalar hacim olarak, finansal kurumlar ise yapı olarak gelişmektedir. Gelişim süreci, sigortacılık alanında da büyümeyi beraberinde getirmektedir. Geliri ve yaşam süresi artan, eğitim düzeyi yüksek toplumlarda, bireylerin bilinç düzeyi de yükselmektedir. İnsani gelişmişliğin yüksek olduğu ülkelerde finansal ihtiyaçlar bireylerin farklı taleplerine göre yeniden şekillenmektedir. İnsani gelişmişlik, farklı ihtiyaçlara uygun yeni finansal hizmetler, araçlar ve ürünlerin geliştirilmesini de zorunlu kilmaktadır.

Çalışmada, önceki çalışmalardan farklı olarak OECD ülkelerinde insani gelişmişlik ve finansal gelişmişlik düzeylerinin sigorta prim üretimleri üzerine etkisi incelenmiştir. Finansal gelişmişlik göstergesi olarak IMF Finansal Gelişme Endeksi (FDI), insani gelişmişlik göstergesi olarak ise Birleşmiş Milletler İnsani Gelişme Endeksi (HDI) verileri kullanılmıştır. IMF tarafından 2016 yılında, 1980 yılı başlangıç yılı alınarak hesaplanmaya başlayan Finansal Gelişme Endeksi (FDI), ülkelerin finansal piyasaları ve finansal kurumlarında derinlik, erişim ve etkinlik kriterleri dikkate alınarak, İnsani Gelişme Endeksi ise gelir, sağlık ve eğitim olmak üzere üç faktör dikkate alınarak hesaplanmaktadır.

OECD ülkelerinde, Finansal Gelişme Endeksi (FDI) ve İnsani Gelişme Endeksi (HDI) ile toplam prim üretimi / gayri safi yurtiçi hasıla (TGP / GDP) oranları arasındaki ilişkilerin incelendiği bu çalışmada, öncelikle birim kök testleriyle değişkenlerin aynı derecen durağan olduğu tespit edilmiş, daha sonra gerçekleştirilen Pedroni ve Kao eşbütünleşme analizleri sonucunda pozitif bulgular elde edilmiştir. Eşbütünleşme testleri ardından Granger nedensellik testleri uygulanmış, analizler sonucunda FDI' den TGP/GDP oranlarına ve HDI' den TGP/GDP oranlarına doğru nedensellik ilişkileri tespit edilmiştir.

Analiz sonuçları beklentiler yönünde olup, OECD ülkelerinde finansal gelişmenin ülkelerdeki finansal çeşitliliği ve derinliği artırdığı, bu süreçle birlikte sigorta prim üretimlerini de etkilediği görülmüştür. İnsani gelişmişlik ise insanların gelir ve eğitim düzeyleri ile yaşam sürelerini artırarak, bireylerin finansal piyasalar ile etkileşimlerini geliştirmektedir. Çalışmada benzer şekilde, OECD ülkeleri için insani gelişmişliğin finansal etkileşimi arttırarak sigorta prim üretimlerini de etkilediği sonucuna ulaşılmıştır. 


\section{KAYNAKÇA}

Akhmat, G.; Zaman, K. ve Shukui, T. (2014). Impact of Financial Development on SAARC'S Human Development. Quality \& Quantity, 48(5), 2801-2816.

Arıç, K.H. (2014). The Effects of Financial Development on Economic Growth in the European Union: A Panel Data Analysis. International Journal of Economic Practices and Theories, 4 (4), e-ISSN 2247-7225 www. ijept.org

Armutçuoğlu Tekin, H.; Ural, M. (2019). Finansal Gelişme ve Ekonomik Performans İlişkisi: OECD Ülkeleri için Bir Analiz. Uluslararası Toplum Araştırmaları Dergisi, 11(18), 43-77.

Arora, R.U. (2012). Financial Inclusion and Human Capital in Developing Asia: The Australian Connection. Third World Quarterly, 33 (1), 177-197.

Aslan, Ö.; Küçükaksoy İ. (2006). Finansal Gelişme ve Ekonomik Büyüme İlişkisi: Türkiye Ekonomisi Üzerine Ekonometrik Bir Uygulama. Ekonometri ve İstatistik, 4, 12-28.

Aydın, M.K.; Ak, M.Z. ve Altıntaş, N. (2014). Finansal Gelişmenin Büyümeye Etkisi: Türkiye Özelinde Nedensellik Analizi. Maliye Dergisi, 167, 149- 162.

Azam, M.; Khan, S.; Zainal, Z.; Karuppiah, N. ve Khan, F. (2015). Foreign Direct Investment and Human Capital: Evidence From Developing Countries. Investment Management and Financial Innovations, 12 (3), 155-162.

Baltagi, B.H.; Bai, C. (2000). Nonstationary Panels, Cointegration in Panels: A Survey. Center for Policy Research Working Paper.

Birleşmiş Milletler (UN). https://www.un.org/en/

Capasso, S. (2003). Financial Markets, Development and Economic Growth: Tales of Informational Asymmetries. University of Naples Parthenope Working Paper Series, 2.

Çelik, İ.E. (2019). Finansal Gelişmişlik Seviyesinin Doğrudan Yabancı Yatırımlar Üzerindeki Rolü: Kırılgan Beşli Ülkeleri Açısından Bir Değerlendirme. Marmara Üniversitesi İktisadi ve İdari Bilimler Dergisi, 41 (1), 65-82.

Dünya Bankası (The World Bank). https://www.worldbank.org/

Evans, A.D.; Green, C.J. ve Murinde, V. (2002). Human Capital and Financial Development in Economic Growth: New Evidence Using the Translog Production Function. International Journal of Finance \& Economics, 7 (2), 123-140.

Giri, A.K.; Sehrawat, M. (2014). The Relationship Between Financial Development Indicators and Human Development in India. International Journal of Social Economics, 41(12), 1194-1208.

Hakeem, M.; Oluitan, O. (2012). Financial Development and Human Capital in South Africa: A Time- series Approach. Research in Applied Economics, 4 (3), 18-38.

Helhel, Y. (2017). E7 Ülkelerinde Finansal Gelişme ve Ekonomik Büyüme Arasında Nedensellik Analizi. Finans Politik \& Ekonomik Yorumlar, 54 (628), 9-18

Huang, Y. (2005). What Determines Financial Development?. Bristol Economics Discussion Papers 05/580, Department of Economics, University of Bristol UK. Erişim Tarihi: 28.08.2019, http://www.bristol.ac.uk/ efm/media/workingpapers/working_papers/pdffiles/dp05580.pdf 
Kaya, A. (2017). Finansal Piyasalardaki Gelişmelerin İnsani Gelişmişlik Üzerine Etkisi: Türkiye Örneği. Uluslararası İktisadi ve İdari İncelemeler Dergisi, 20, 169-180

Khan, M.; Qayyum, B. (2007). Trade Liberalisation, Financial Development and Economic Growth. Pakistan Institute of Development Economics Working Paper, No. 22204.

Koç, S.; Şenol, Z. ve Karaca, S.S. (2016). Finansal Gelişmişliği Etkileyen Makroekonomik Faktörlerin Gelişmiş ve Gelişmekte Olan Ülkeler Örnekleminde Analizi: 2000-2012. Journal of Economics, Finance and Accounting, 3 (4), 299-319.

Kuloğlu, A.; Ecevit, E. (2017). The Relationship Between Health Development Index And Financial Development Index: Evidence From High Income Countries. Ekonomi, Politika \& Finans Araştırmaları Dergisi, 2(2), 8395.

Levine, R. (1997). Financial Development and Economic Growth: Views and Agenda. Journal of Economic Literature, 35 (2), 688-726.

Mercan, M.; Peker, O. (2013). Finansal Gelişmenin Ekonomik Büyümeye Etkisi: Ekonometrik Bir Analiz. Eskişehir Osmangazi Üniversitesi İİBF Dergisi, 8 (1), 93-120.

Murthy, D. S.; Samantaraya, A. (2014). Assessing Financial Development in India and Its Relation with Economic Growth: An Empirical Analysis. Journal of Economic and Financial Modelling, 2 (1), 1-12.

OECD. https://www.oecd.org/

Outreville, J. F. (1999). Financial Development, Human Capital and Political Stability. United Nations Conference on Trade And Development. UNCTAD/OSG/DP/142, Erişim Tarihi:22.07.2019, https://www.researchgate. net/profile/J_Outreville/publication/23694132_Financial_Development_Human_Capital_and_Political_ Stability/links/551bc82a0cf2fe6cbf75e82a/Financial-Development-Human-Capital-and-Political-Stability. pdf?origin=publication_detail

Öztürk, N., Kılıç Darıc1, H. ve Kesikoğlu F. (2011). Ekonomik Büyüme ve Finansal Gelişme İlişkisi: Gelişmekte Olan Piyasalar İçin Bir Panel Nedensellik Analizi. Marmara Üniversitesi İİBF Dergisi, 30 (1), 53-69.

Patrick, H.T. (1966). Financial Development and Economic Growth in Underdeveloped Countries. Economic Development and Cultural Change, 14, 174-189.

Pedroni, P. (1999). Critical Values for Cointegration Tests in Heterogeneous Panels with Multiple Regressors. Oxford Bulletin Of Economics and Statistics, 61, 653-670

Ranis, G.; Stewart, F. ve Ramirez, A. (2000). Economic Growth and Human Development. World Development, 28 (2), 197-219.

Saci, K.; Holden, K. (2008). Evidence on Growth and Financial Development Using Principal Components. Applied Financial Economics, 18 (19), 1549-1560.

Sahay, R.; Cihak, M.; N’Diaye, P. vd. (2015). Rethinking Financial Deepening: Stability and Growth in Emerging Markets. IMF Staff Discussion Notes (SDNs), Erişim Tarihi: 22.07.2019, https://www.imf.org/external/pubs/ $\mathrm{ft} / \mathrm{sdn} / 2015 / \mathrm{sdn} 1508 . \mathrm{pdf}$

Sayılır, Ö.; Doğan, M. ve Soud, N.S. (2018). Financial Development and Governance Relationships. Applied Economics Letters, Taylor \& Francis Journals, 25 (20), 1466-1470. 
Satrovic, E. (2017). Financial Development and Human Capital in Turkey. Kapadokya Akademik Bakış, 1(2), $1-15$.

Svirydzenka, K. (2016). Introducing A New Broag-based Index of Financial Development. IMF Working Paper.

Şenol, Z. (2019). Finansal Gelişim ile İnsani Gelişim Arasındaki İlişki: Gelişmiş ve Gelişmekte Olan Ülkeler Örneği. Uluslararası Yönetim İktisat ve İşletme Dergisi, 15 (2), 341-358.

Todaro, M.P. (1992). Human Development Report 1992. Population and Development Review, 18(2), 359- 363.

Tüylüoğlu, Ş.; Karalı, B. (2005). İnsani Kalkınma Endeksi ve Türkiye İçin Değerlendirilmesi. Selçuk Üniversitesi İ̈BF Sosyal ve Ekonomik Araştırmalar Dergisi, 12, 53-89.

Uluslararası Para Fonu (IMF). https://www.imf.org

UNDP (1996). Human Development Report, http://hdr.undp.org/en/reports/

UNDP (2010). Human Development Report, http://hdr.undp.org/en/reports/

Yardımcıoğlu F.; Gülmez, A. (2013). OPEC Ülkelerinde Hollanda Hastalı̆̆ı: Petrol Fiyatları ve Ekonomik Büyüme İlişkisinin Ekonometrik Bir Analizi. Sosyoekonomi, 19, 117-140.

Zortuk, M.; Ebeoğlugil, H.F. (2016). Seçilmiş Geçiş Ekonomilerinde İnsani Kalkınma ve Sigorta İlişkisi: Ampirik Bir Çalışma. Dumlupınar Üniversitesi Sosyal Bilimler Dergisi, Afro-Avrasya Özel Sayısı - Aralık, 378-395 